\title{
Comparative anatomical study on infundibulum of Pati and Chara- Chemballi ducks (Anas platyrhynchos domesticus) during laying periods
}

\author{
Anil Deka ${ }^{1}$, Gajen Baishya ${ }^{1}$, Kabita Sarma ${ }^{1}$ and Manjyoti Bhuyan ${ }^{2}$
}

1. Department of Veterinary Anatomy and Histology, College of Veterinary Science, Assam Agricultural University, Khanapara, Guwahati- 781022, Assam, India; 2. Department of Animal Reproduction, Gynaecology \& Obstetrics, College of Veterinary Science, Assam Agricultural University, Khanapara, Guwahati- 781022, Assam, India. Corresponding author: Manjyoti Bhuyan, email: mitumanjyoti@gmail.com

Received: 27-02-2014, Revised: 24-03-2014, Accepted: 27-03-2014, Published online: 29-04-2014

doi: 10.14202 /vetworld.2014.271-274

How to cite this article: Deka A, Baishya G, Sarma K and Bhuyan M (2014) Comparative anatomical study on infundibulum of Pati and Chara-Chemballi ducks (Anas platyrhynchos domesticus) during laying periods, Veterinary World 7(4): $271-274$.

\begin{abstract}
Aim: The present investigation was undertaken to establish anatomical norms on gross anatomical, histomorphological and histochemical parameters of infundibulum of Pati and Chara-Chemballi ducks.

Materials and Methods: In the present investigation, 12 (twelve) each Pati and Chara-Chemballi ducks in their laying period (42 weeks age) were utilized.

Results: The mean length, breadth, thickness and weight of infundibulum were significantly higher in Chara-Chemballi duck than Pati duck. Though most of the histological parameters are almost similar, but the mean height of lamina epithelialis mucosae was significantly higher in Chara-Chemballi duck $(30.234 \pm 0.389 \mu \mathrm{m})$ than in Pati duck $(23.906 \pm 0.332 \mu \mathrm{m})$. PAS reaction was moderate at apical part of lining epithelium in Chara-Chemballi duck whereas the same is weak in Pati duck.
\end{abstract}

Conclusion: Result obtained showed that the Chara-Chemballi duck revealed significant difference in all the parameters as compared to Pati duck.

Keywords: anatomy, Chara-Chemballi, duck, infundibulum, Pati.

\section{I ntroduction}

Duck husbandry plays an important role in the socio-economic upliftment of the rural poor of Assam and other states located in the coastal regions of India. It is one of the most important domesticated species of poultry next to chicken primarily reared for table egg production in India. The peculiar agro-climatic condition with marshy and waterlogged areas prevailing throughout the state provides a very congenial environment for rearing ducks in Assam. Duck husbandry provides an additional source of income to the rural women folk of these states. The 'Pati' duck population constitutes a major indigenous non-descript duck variety in the state of Assam and annual egg production per duck is 70-95 eggs [1]. However, Chara-Chemballi duck is an indigenous variety of Kerala but their production performance did not differ significantly and annual egg production per duck was 181.3 with an average egg weight of $71.6 \pm 2.38 \mathrm{~g}$ at 72 weeks of age under free range condition of Assam [2].

Infundibulum plays an important role in capturing and transferring of ovum and formation of chalazae [3]. Although research works have been conducted on the infundibulum part of the oviduct in domestic fowl [4, $5,6,7]$, literature regarding the infundibulum of Pati and Chara-Chemballi ducks during laying periods is found to be very scanty.

Copyright: The authors. This article is an open access article licensed under the terms of the Creative Commons Attribution License (http://creativecommons.org/licenses/by/2.0) which permits unrestricted use, distribution and reproduction in any medium, provided the work is properly cited.
Therefore, in the present investigation, it was envisaged to study the gross, histology and histochemistry (PAS) of infundibulum of Pati and CharaChemballi duck during laying periods.

\section{Materials and Methods}

Ethical approval: The prior approval from the Institutional Animal Ethical Committee was obtained for use of the animals in this study.

Experimental design: In the present investigation, 12 (twelve) each Pati and Chara-Chemballi ducks in their laying period (42 weeks age) were utilized. The Pati and Chara-Chemballi ducks were procured from Pathsala locality of Barpeta district and State Institute and Rural Development, Khanapara, Guwahati respectively. The infundibulums were collected immediately after sacrifice as per the standard method [8] and gross studies were made on it. After slaughter, the location and relative topographic in-situ position of the infundibulum were recorded. The infundibulums were taken out from the body of birds and weights of infundibulum were recorded with the help of electronic pan balance. The gross anatomical characteristics of infundibulum were studied and the different biometrical measurements viz., the length, breadth and thickness of infundibulum were recorded by Verniercallipers [9]. For histological, histochemical and micrometrical study infundibulum were collected from of 42 weeks age of Pati and Chara-Chemballi ducks. The tissue samples were fixed in $10 \%$ neutral buffered formalin. Then tissues were processed for Paraffin embedding method. 
Table-1: Average of various traits of infundibulum of Pati and Chara-Chemballi ducks along with the results of ' $t$ ' test.

\begin{tabular}{lccc}
\hline Traits & \multicolumn{2}{c}{ Genetic groups } & \multirow{2}{*}{ 't' value } \\
\cline { 2 - 3 } & Pati duck & Chara-Chemballi duck & \\
\hline Length $(\mathrm{cm})$ & $5.28 \pm 0.10$ & $7.84 \pm 0.23$ & $9.905^{\text {** }}$ \\
Breadth $(\mathrm{cm})$ & $0.70 \pm 0.02$ & $0.95 \pm 0.00$ & $8.176^{\star *}$ \\
Thickness $(\mathrm{cm})$ & $0.45 \pm 0.03$ & $0.56 \pm 0.01$ & $2.896^{\star *}$ \\
Weight $(\mathrm{g})$ & $0.79 \pm 0.02$ & $1.20 \pm 0.07$ & $5.236^{\star *}$ \\
Height of lamina epithelialis & & & \\
mucosae of infundibulum $(\mu \mathrm{m})$ & $23.906 \pm 0.332$ & $30.234 \pm 0.389$ & $12.35^{\text {** }}$ \\
\hline
\end{tabular}

** Highly significant $(\mathrm{P}<0.01)$

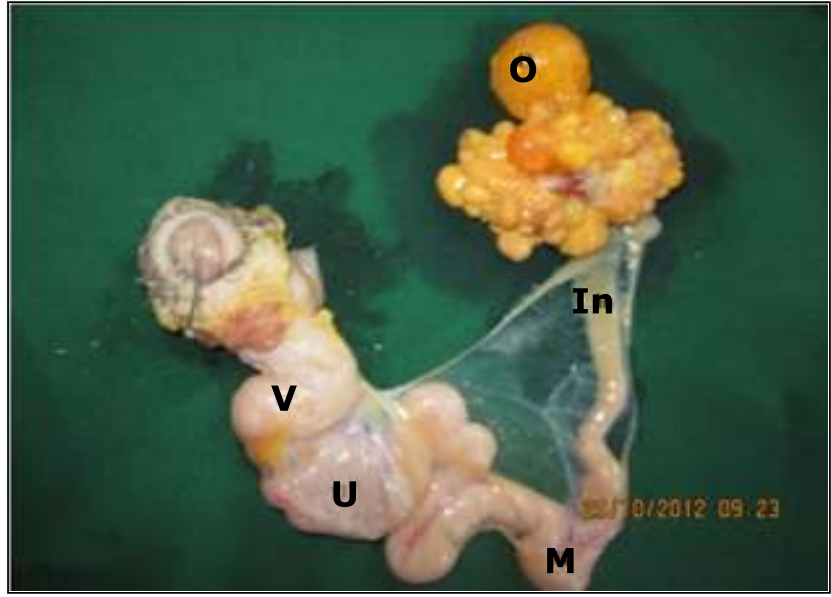

Figure-1: Photograph showing the ex-situ position of female reproductive system of Pati duck showing ovary (O) infundibulum (In), magnum (M), uterus (U) and vagina (V).

Paraffin sections were cut in five micron thickness and stained with Hematoxylin and Eosin method for histomorphological study, Van Gieson's method for collagen fibre, Gomori's method for reticular fibre, Hart's method for elastic fibre, Bielschowsky's method for axis cylinder and dendrites and Mc.Manus method for glycogen [10]. After staining, histological characteristics of infundibulum were recorded. Different micrometrical parameters were recorded on Hematoxylin and Eosin stained section by means of standard method of micrometry using Nikon E 200 camera mounted microscope and Image Pro Express Ver-2.0 Software.

Statistical analysis: The data were analyzed as per ' $\mathrm{t}$ ' test method described by Snedecor and Cochran [11].

\section{Results and Discussion}

In the current study, the gross anatomical relationship and length, breadth, thickness and wieght of infundibulum of Pati and Chara-chemballi ducks were recorded. The infundibulum of Pati and CharaChemballi duck consisted of a wide funnel shaped membranous part and a short tubular part. The wide funnel part opened immediately caudal to the ovary and had no direct attachment to the ovary (Figure- 1 and Figure-2). The demarcation was in consonance to the finding of Fujii [12] in fowl, Saber et al. [13] in ostrich, Sharaf et al. [14] in ostrich, Balasundaram et al. [15] in Emu. The tubular part of infundibulum was connected to the magnum by a constricted junction. In present study the mean length, breadth, thickness and weight of

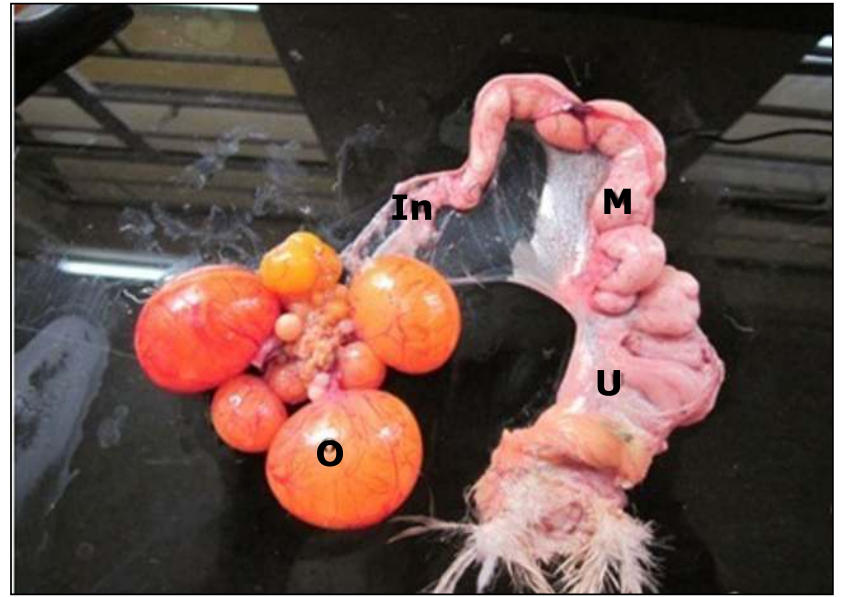

Figure-2: Photograph showing the ex-situ position of female reproductive system of Chara-Chemballi duck showing ovary (O), infundibulum (In), magnum (M) and uterus (U).

infundibulum were $5.28 \pm 0.01 \mathrm{~cm}, 0.70 \pm 0.02 \mathrm{~cm}, 0.45$ $\pm 0.03 \mathrm{~cm}$ and $0.79 \pm 0.02 \mathrm{~g}$ respectively in Pati ducks. Corresponding values for the Chara-Chemballi ducks were $7.84 \pm 0.23 \mathrm{~cm}, 0.95 \pm 0.00 \mathrm{~cm}$ and $0.56 \pm 0.01 \mathrm{~cm}$ and $1.20 \pm 0.07 \mathrm{~g}$ (Table-1). Contrary to the present findings, Romanoff and Romanoff [16] recorded the length of infundibulum in laying hen to be $7 \mathrm{~cm}$ while Khokhlov [17] marked that its length and weight was $9.7 \pm 0.8 \mathrm{~cm}$ and $1.0 \pm 0.3 \mathrm{~g}$ respectively in sexually matured hen. However, Parto et al. [18] reported that the length of infundibulum was $7 \mathrm{~cm}$ in laying turkey. These might be due to difference in size and age of the birds.

Histologically, the tunica mucosa of infundibulum of both Pati and Chara-chemballi duck was highly folded and numerous slender folds extended towards the lumen of infundibulum. The folds were of three types viz., primary, secondary and tertiary types (Figure-3 and Figure-4). Similar finding were also reported by Bacha and Bacha [19] in fowl. The lamina epithelialis mucosae of infundibulum consisted of simple ciliated columnar with some goblet cells in both Pati and Chara-Chemballi ducks. These results were in accordance with the findings of Moraes et al. [20] in Ana Bochas female ducks, Mehta and Guha [21] in laying hen, Patki et al. [22] in Kuttanad duck and Mirhish and Nsaif [23] in turkey hen. Lamina propriasubmucosa contained areolar connective tissue with branched tubular glands. This finding was corroborated with the finding of Lucy and Harshan [24] in Japanese quail. This layer contained large amount of 


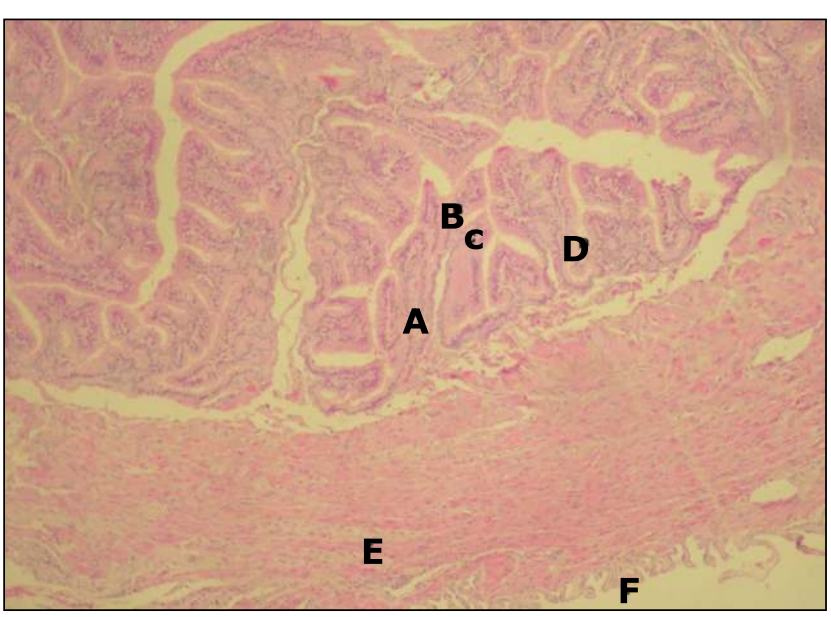

Figure-3: Photomicrograph showing the infundibulum of Pati duck along with primary $(A)$, secondary $(B)$, tertiary folds (C), glandular grooved (D), tunica muscularis (E) and tunica serosa (F). H\&E, 100X

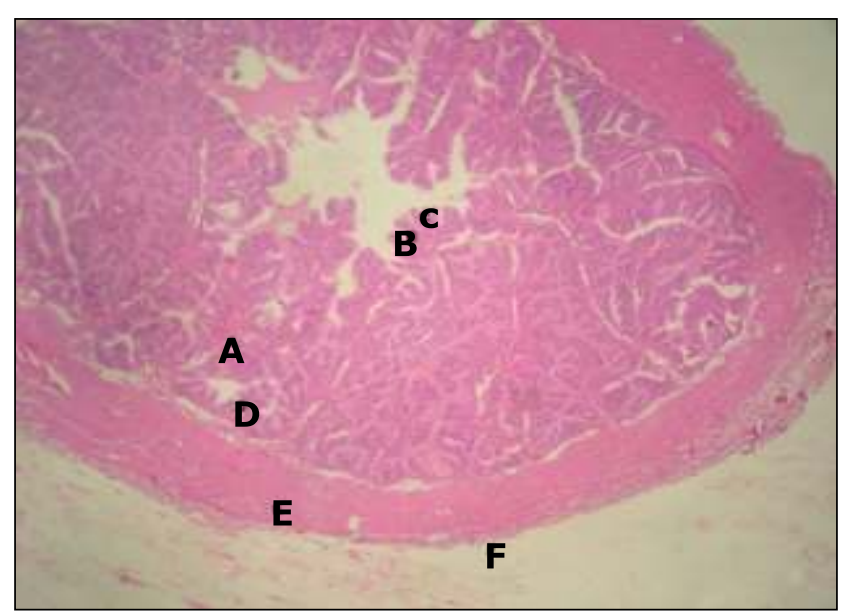

Figure-4: Photomicrograph showing the infundibulum of Chara-Chemballi duck along with primary (A), secondary (B), tertiary folds (C), glandular grooved (D), tunica muscularis (E) and tunica serosa (F). H\&E, 100X

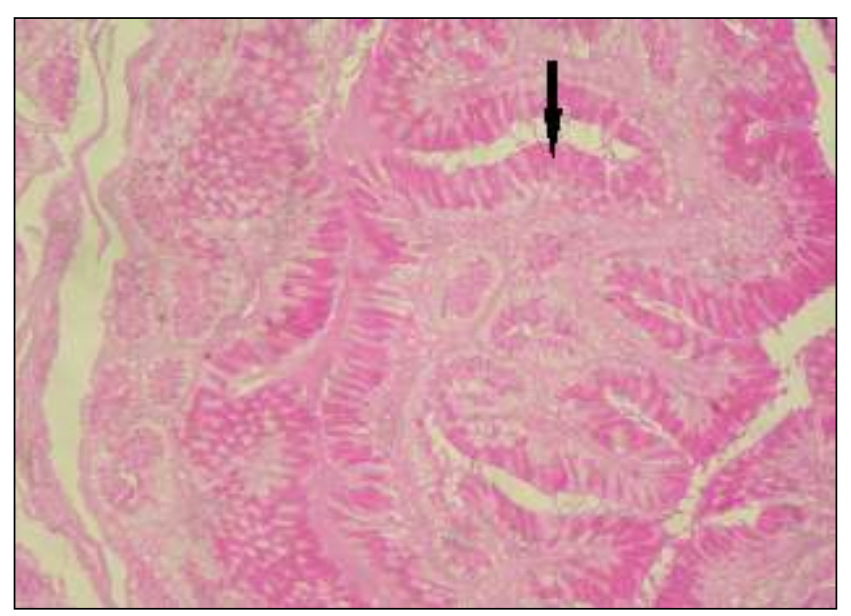

Figure-5: Photomicrograph showing the moderate PAS reaction in the lining epithelium (arrow) of infundibulum of Chara-Chemballi duck. Mc. Manus Method for Glycogen (PAS), 400X.

reticular fibres with scanty amount of collagen and elastic fibers as well as nerve fibres in Chara-Chemballi duck as compared to Pati duck. Similar findings were recorded by Ghule et al. [25] in Japanese quail. These probably might be due to different varieties of ducks. The tunica muscularis was composed of inner circular and outer longitudinal smooth muscle layers and tunia serosa was formed by loose connective tissue, blood vessels, lymph vessels and nerve fibres. The tunica serosa layers contained large amount of reticular and elastic fibres and less amount of collagen fibers along with nerve fibers in Chara- Chemballi duck as compared to Pati duck. These results were corroborated with Geetha et al. [26] in Japanese quail. The mean height of lamina epithelialis mucosae was significantly higher in Chara-Chemballi duck $30.234 \pm 0.389 \mu \mathrm{m}$ than Pati duck was 23.906 $\pm 0.332 \mu \mathrm{m}$ (Table-1). Khokhlov [17] reported that the height of lamina epithelialis mucosae to be $12.9 \pm 0.8 \mu \mathrm{m}$ in hens at 150 days of age. These might be due to size and age of the birds. However, Mohammadpour and Keshtmandi [27] found that the length of mucosal fold of infundibulum in pigeon was
500.47 $\pm 57.7 \mu \mathrm{m}$ Whereas Bansal et al. [28] reported that the height of epithelium of caudal part of infundibulum in Panjab white quail was $37.43 \pm 11.24 \mu \mathrm{m}$.

Histochemically, PAS reaction was moderate at apical part of lining epithelium, weak in central part of folds and in lamina propria-submucosa in CharaChemballi duck (Figure-5). However, in Pati duck, PAS positive reaction was weak in the apical part of lining epithelium, central part of folds and in lamina propria-submucoa. This was in accordance with the findings of Joaquim et al. [29] in Muscovy ducks. These might be due to more amount of glycogen in infundibulum of Chara-Chemballi duck than Pati duck.

\section{Conclusion}

The results from the present study suggests that grossly the infundibulum of Pati and Chara-Chemballi ducks consisted of a wide funnel shaped membranous part and a short tubular part. The wide funnel part opened immediately caudal to the ovary and had no direct attachment to the ovary. All the parameters like length, breadth, thickness and weight of infundibulum 
of Chara-Chemballi duck were significantly higher than Pati duck. Histologically, the tunica mucosa of infundibulum of both Pati and Chara-chemballi duck was highly folded and numerous slender folds extended towards the lumen of infundibulum. The folds were of three types viz., primary, secondary and tertiary types. The mean height of lamina epithelialis mucosae was significantly higher in Chara-Chemballi duck than Pati duck. Histochemically, PAS reaction was moderate at apical part of lining epithelium in Chara-Chemballi duck whereas in Pati duck PAS positive reaction was weak in the apical part of lining epithelium.

It might, therefore be concluded that the observations in the present study established a major role in recording the anatomical norms in respect of gross, histology and histochemistry (PAS) of infundibulum of both Pati and Chara-Chemballi ducks. These will help physiologist, pathologist and poultry scientists for effective production strategies as well as disease control regime in duck husbandry.

\section{Authors' contributions}

$\mathrm{AD}$ and $\mathrm{GB}$ designed and planned the study. The experiment was done by $\mathrm{AD}$. KS and $\mathrm{MB}$ analyzed the data. All authors participated in draft and revision of the manuscript. All authors read and approved the final manuscripts.

\section{Acknowledgements}

The authors are thankful to the Dean, Faculty of Veterinary Science for providing necessary laboratory facilities to carry out the research work smoothly. The authors are thankful to The Director of Post-graduate studies, Assam Agricultural University for financial assistance.

\section{Competing interests}

The authors declare that they have no competing interests.

\section{References}

1. Kalita, N., Barua, N., Bhuyan, J. and Chidananda B. L. (2009) Present status of duck farming in Assam. Proceeding of $4^{\text {th }}$ world waterfowl conference. Thrissur, India, p359-363.

2. Mahanta, D. J., Deka, R. J., Supcota, D. and Jalaludeen, A. (2009) Certain performances traits of Chara-Chemballi ducks of Kerala under range condition in Assam. Proceeding of $4^{\text {th }}$ world waterfowl conference. Thrissur, India, p136-138.

3. Patki, H. S., Lucy, K. M., Harshan, K. R. and Chungath, J. J. (2009) Morphological studies on the infundibulum of Kuttanad duck (Anas Platyrhynchos domesticus) during postnatal period. J. Vet. Anim. Sci. 40: 22-25.

4. Aitken, R. N. C. and Johnston, H. S. (1963) Observation on the fine structure of the infundibulum of the avian oviduct. $J$. Anat. 97: 87-89.

5. Hodges, R. D. (1974) The histology of Fowl. Academic Press, London, p648.

6. King, A. S. (1975) Aves-Urogenital system. In:Getty, R.(Ed.) Sisson and Grossman's the Anatomy of the Domestic Animals. $5^{\text {th }}$ Ed. W. B. Saunders, Philadelphia, p1935-1959.

7. Nickel, R., Schummer, A. and Sieferle, E. (1977) Anatomy of the Domestic Birds. Verlag Paul Parey, Berlin, p202.

8. Gracey, J. F. (1968) Bleeding method of slaughteringslaughter. Meat Hygiene. $8^{\text {th }}$ Ed. p144-145.
9. McCance, R. A. (1974) The effect of age on the weights and lengths of pig's intestine. J. Anat.117 (3): 475-479.

10. Luna, L.G. (1968) Manuals of histological staining methods of armed forces institute of pathology, $3^{\text {rd }} \mathrm{Ed}$. McGraw Hill Book Co., London, p 37-193.

11. Snedecor, G. W. and Cochran, W. G. (1967) Statistical Methods. $6^{\text {th }}$ Ed. University Press Ames, Iowa, USA, p 120-134.

12. Fujii, S.,Yoshimura,Y., Okamoto, T. and Tamura, T. (1981) The regional morphology of the infundibulum of the hen's oviduct with special reference to the mechanism of the engulfing of the ovulated ovum.J. Fac. App. Bio. Sci. 10:87-94.

13. Saber, A. S., Emara, S. A. M. and Abosaeda, O. M. M. (2010) Light, Scanning and transmission electron microscopical study on the oviduct of the ostrich (Struthio camelus). J. Vet. Anat. 2(2): 79-89.

14. Sharaf, A., Eid, W. and Atta, A. A. A. (2012) Morphological aspect of the ostrich infundibulum and magnum. Bulg. J. Vet. Med.15 (3): 145-159.

15. Balasundaram, K., Kumar, V. and Paramasivan, S. (2014) Light microscopy of the infundibulum and magnum of Emu (Dromaius novaehollandiae). Proceeding of the $28^{\text {th }}$ National Symposium on Veterinary Anatomy Vision 2050Improvement, Challenges and opportunities in Relation to Animal as well as Human Health and Biodiversity. Bikaner, Rajasthan, p127.

16. Romanoff, A. L. and Romanoff A. J. (1949) The Avian Egg. New York; John Wiley, p918.

17. Khokhlov, R.Y. (2008) Morphology of an infundibulum of the oviduct of the sexually mature hens. Int. J. Mor. 26(4): 883-886.

18. Parto, P., Khaksar, Z., Akramifard, A. and Moghii, B. (2011) The microstructure of oviduct in laying turkey hen as observed by light and scanning electron microscopies. World J.Zoo.6 (2): 120-125.

19. Bacha, W. J. and Bacha, L. M. (1990) Color Atlas of Veterinary Histology. $2^{\text {nd }}$ Ed. Black well, p224.

20. Moraes, C., Baraldi-Artoni, S. M., Pacheco, M. R., Nishizawa, M. and Nakaghi, L. S. O. (2010) Morfologia e histologia do oviduct de marrecas Ana boschas. Arq. Bras. Med. Vet.Zootec. 62(2): 293-301.

21. Mehta, S. and Guha, K. (2012) Comparative Histological study on the oviduct of developing and laying hens (Gallus domesticus). Ind. J. Vet. Anat. 24(2): 92-94.

22. Patki, H. S., Lucy, K. M. and Chungath, J. J. (2013) Histological observation on the Infundibulum of Kuttanad duck (Anas platyrhynchos domesticus) during postnatal periods. Int. J. Sci. and Res. Pub.3 (1): 1-8.

23. Mirhish, M. S. and Nsaif, H. R. (2013) Histological study of the ovary and infundibulum of Turky hen (Meleagris gallopavo). Ba.J. Vet. Res. 12(2):11-16.

24. Lucy, K. M. and Harshan, K. R. (1999) Structure and postnatal development of infundibulum in Japanese quail. Indian J. Poult. Sci. 34(2): 125-128.

25. Ghule, P. M., Gaikwad, S. A., Dhande, P. L., Lambate, S. B., Patil, A. D., Tiwari, S.S. and Ayana, R. (2010) Histomorphological study of the oviduct in Japanese quail. Indian J. Vet. Anat. 23 (1): 40-42.

26. Geetha, S.,Venkatakrishan, A. and Vijayaragavan, C. (1992) A preliminary study of the histomorphology and histochemistry of the oviduct of Japanese quail (Coturnix coturnix japonica). Indian J. Vet. Anat. 4: 96-97.

27. Mohammadpour, A. A. and Keshtmandi M. (2008) Histomorphophometrical study of infundibulum and magnum in Turkey and Pigeon. World J. Zoo. 3(2): 47-50.

28. Bansal, N., Uppal, V., Pathak, D. and Brah, G. S. (2010) Histochemical and histochemical studies on the oviduct of Punjab White quails. Indian J. Poult. Sci. 45 (1): 88-92.

29. Joaquim, E. and Baratella, L. (1997) Morphological and histolochemical aspects of the luminal oviductal epithelium of the laying and non-Laying muscovy duck (Cairina moschata, Linneaus, 1758). Rev. Chil. de anat.15(2):1-13.

$* * * * * * * *$ 